\title{
Łęczyckie wiatraki - inicjatywy konserwatorskie z lat 2006-2017 na przykładzie „Zagrody Młynarskiej” w Uniejowie
}

\author{
Filip Tomaszewski, Bartosz M. Walczak \\ Zaktad Historii Architektury, Rewitalizacji i Konserwacji Zabytków, Instytut Architektury i Urbanistyki, \\ Wydział Budownictwa, Architektury i Inżynierii Środowiska, Politechnika Łódzka, \\ e-mail:bogdan.tomaszewski@wp.pl,bartosz.walczak@p.lodz.pl
}

Streszczenie: Zabytkowe wiatraki stanowią istotny składnik krajobrazu kulturowego ziemi łęczyckiej. Artykuł przedstawia inicjatywy mające na celu zachowanie i utrwalenie w krajobrazie tych niezwykłych zabytków architektury drewnianej, ze szczególnym uwzględnieniem budowy t.zw. „Zagrody Młynarskiej” w Uniejowie. Zły stan zachowania większości z zachowanych do dzisiaj łęczyckich wiatraków determinował (i determinuje nadal) szeroki i zróżnicowany zakres podjętych działań konserwatorskich. Poza realizacją „Zagrody Młynarskiej” obejmował on budowę skansenu „Łęczycka Zagroda Chłopska” w Kwiatkówku, podjętą przez Muzeum Archeologiczne i Etnograficzne w Łodzi oraz zachowawcze remonty in situ wiatraków w Solcy Wielkiej i Rdutowie Nowym. Relokacja zabytkowych wiatraków stwarza możliwość przywrócenia ich do sprawności technicznej, jednak kosztem wymiany znacznego procenta ich oryginalnej substancji. Artykuł omawia stopień autentyczności, jaki udało się uzyskać w konserwowanych obiektach, zakres ingerencji w ich pierwotną strukturę, rolę wiatraków w kształtowaniu krajobrazu kulturowego, a także zagadnienia związane $\mathrm{z}$ wyposażeniem technicznym młynów oraz problemy związane z utrzymaniem ich w ruchu.

Słowa kluczowe: młyn, wiatrak, remont, konserwacja.

\section{Wprowadzenie}

Zabytkowe wiatraki stanowią istotny składnik krajobrazu kulturowego ziemi łęczyckiej. Są one dzisiaj zabytkami zarówno architektury, jak i techniki - tym cenniejszymi, że zachowanymi w bardzo już małej liczbie. Jak pisze Jan Święch w książce Tajemniczy świat wiatraków: „W dobie żywych dyskusji na temat ochrony środowiska naturalnego, wiatraki są przykładem urządzeń przemysłowych, które nie tylko nie degradują środowiska, ale ich ciekawa architektura, bezbłędna kompozycja dostosowana do warunków geograficznych i przyrodniczych terenu, wzbogaca go, tworząc fenomen harmonijnie ukształtowanego krajobrazu kulturowego" [1]. Ochrona zabytkowych wiatraków jest zadaniem trudnym. Obiekty te, pozbawione w okresie po II wojnie światowej pierwotnej funkcji (a pracowały głównie jako młyny przemiałowe), uległy bądź to rozbiórce, bądź postępującej degradacji technicznej. Do zagłady wiatraków w Polsce przyczyniły się przede wszystkim: postęp techniczny w młynarstwie (przejawiający się w zwiększeniu wydajności produkcji) oraz polityka gospodarcza w okresie komunizmu (nacjonalizacja, niszczenie drobnej wytwórczości). Większość wiatraków zamykano, nieliczne zaś przekształcano w młyny elektryczne, co niejednokrotnie wiązało się ze zmianami w technologii i architekturze budynków. Po śmierci dawnych młynarzy proces degradacji młynów nasilił się, ponieważ młodsze pokolenia nie 
były zainteresowane utrzymaniem wiatraków w należytej kondycji. Należy podkreślić fakt, że obiekty te trudno jest zaadaptować do nowych funkcji, zwłaszcza o charakterze komercyjnym. Ekonomiczny sens ich dalszej egzystencji stanął zatem pod znakiem zapytania. Można śmiało stwierdzić, że wiatraki powinniśmy chronić nie tylko jako zabytki techniki (z ich cennym wyposażeniem), ale także jako znaki w krajobrazie, podobnie jak chronimy szałasy pasterskie w górach - w obu przypadkach szukanie dla nich nowych funkcji może okazać się problematyczne. Ziemia łęczycka jest obszarem, gdzie w ostatnich latach udało się przeprowadzić kilka udanych inicjatyw mających na celu zachowanie wiatraków dla przyszłych pokoleń. Artykuł niniejszy opisuje jedną z nich - budowę tak zwanej „Zagrody Młynarskiej” w Uniejowie, do której udało translokować dwa wiatraki z terenu powiatu łęczyckiego. Pozostałe przykłady działań konserwatorskich dotyczących młynów wietrznych zostały jedynie przywołane z uwagi na ograniczoną objętość niniejszej publikacji. Artykuł oparty jest na doświadczeniach własnych współautora niniejszego artykułu - architekta Filipa Tomaszewskiego. Pod pojęciem „ziemia łęczycka” rozumie się nie tylko teren obecnego powiatu łęczyckiego, ale obszar zamknięty granicami województwa łęczyckiego z lat 1351-1793 [2].

Wszystkie wiatraki, jakie udało się do dnia dzisiejszego zachować na ziemi łęczyckiej należą do typu tzw. „koźlaków” - najstarszego typu młynów wietrznych, istniejących na ziemiach polskich od końca XIII wieku [3]. Wiatraki te posadowione są na „koźle” - drewnianym postumencie, którego centralną część stanowi solidny drewniany słup zwany „,sztembrem". Ściany takiego wiatraka zostały tak skonstruowane, że nie stykają się z ziemią, lecz zawieszone są nad nią na wysokości kilkunastu centymetrów. Dlatego z daleka wiatrak robi wrażenie solidnej budowli trwale związanej z gruntem. Tymczasem przemyślana konstrukcja umożliwiała obrót (wokół „sztembra”) całego budynku skrzydłami do kierunku wiatru.

\section{2. „Zagroda Młynarska” w Uniejowie}

Zabytkami młynarstwa wietrznego z terenu ziemi łęczyckiej, które udało się w ostatnim czasie odrestaurować, są między innymi wiatraki z miejscowości Chorzepin i Zbylczyce w gminie Świnice Warckie. Zostały one relokowane do Uniejowa w ramach budowy w latach 2010-2012 tzw. „Zagrody Młynarskiej” (Fot. 1). Nie jest to rekonstrukcja jakiejś konkretnej, historycznej zagrody młynarza, stanowi raczej konglomerat zabytkowych obiektów lub ich kopii skomponowany pod kątem współczesnych potrzeb użytkowych zespołu muzealno-noclegowego. Obejmuje on cztery oryginalne zabytkowe obiekty architektury drewnianej przeniesione $\mathrm{z}$ terenu województwa łódzkiego. Poza wyżej wymienionymi wiatrakami są to dwór z Nagórek oraz chałupa ze Skotnik. Ponadto na terenie kompleksu wzniesiono kopie drewnianej stodoły z Besiekier i murowanego budynku inwentarskiego z Uniejowa oraz współczesny budynek biurowo-gospodarczy. Inwestycja zrealizowana została przez Gminę Uniejów, przy znaczącym udziale środków europejskich w ramach projektu „Termy Uniejów - Regionalny Markowy Produkt Turystyki Uzdrowiskowej”. Wszystkie wymienione obiekty nie były objęte rejestrem zabytków, widniały jedynie w ewidencji. Inwestycja stanowi interesujący przykład komercyjnego wykorzystania zabytków. Wiatrak ze Zbylczyc przeznaczony został na cele muzealne (możemy tu mówić o zachowaniu ciągłości funkcji młyna przemiałowego), zaś wiatrak z Chorzepina zaadaptowano do celów noclegowych (jedyny jak na razie przykład adaptacji „łęczyckiego" wiatraka do nowych funkcji), w chałupie ze Skotnik urządzono niewielką karczmę, dwór z Nagórek zaadaptowano na pensjonat, a budynek stodoły przeznaczono na miejsce organizacji imprez firmowych, warsztatów i konferencji. Ciągłość funkcji zachował budynek inwentarski, który służy obecnie jako stajnia. 


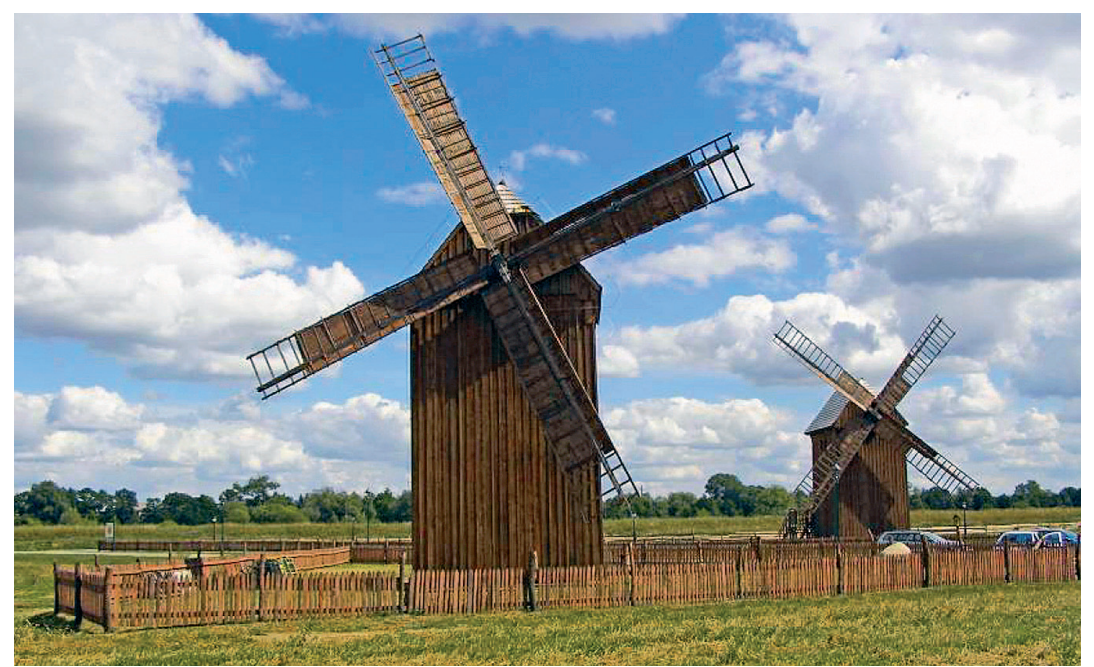

Fot. 1. Wiatraki w „Zagrodzie Młynarskiej” w Uniejowie (sierpień 2012 r.), fot. F. Tomaszewski

Wiatrak z Chorzepina (Fot. 2) według Katalogu zabytków budownictwa przemysłowego $w$ Polsce [4] datowany jest na rok 1644, natomiast według wojewódzkiej ewidencji zabytków młyn pochodzi z wieku XIX. Wątpliwości dotyczące datowania obiektu należałoby rozstrzygnąć na podstawie badań dendrochronologicznych. Nadmienić należy, że wiatrak w Chorzepinie uwidoczniony był już na mapie Gilly’ego [5], a więc jego metryka może być wcześniejsza niż dziewiętnastowieczna. Wiatrak w swojej pierwotnej lokalizacji bardzo harmonijnie wpisywał się w krajobraz. Niestety katastrofalny stan techniczny obiektu i całkowity brak zainteresowania jego utrzymaniem ze strony właścicieli zdeterminował przeniesienie zabytku. W przypadku wiatraków relokacja jest często trudną decyzją: kontekst przestrzenny ma dla tych obiektów fundamentalne znaczenie - chroniąc wiatrak in situ zachowujemy cały otaczający go krajobraz kulturowy (n.p. w Holandii relokacja wiatraków dopuszczalna jest wyłącznie jako ostateczność podyktowana wyższym celem społecznym [6]). W przypadku wiatraka z Chorzepina poza konstrukcją kozła, „pojazdami” oraz „mącznicą” (które zachowały się w stanie niemal nienaruszonym) cały budynek wymagał rekonstrukcji. Z wyposażenia udało się zachować główne koło napędowe, tzw. koło paleczne, natomiast wał skrzydłowy został zastąpiony wałem pochodzącym z innego wiatraka, wyposażonym w żeliwną głowicę. Obecnie wiatrak z Chorzepina zaadaptowany jest do funkcji noclegowych w taki sposób, aby ingerencja w jego pierwotną strukturę była jak najmniejsza. Szkieletowe ściany wiatraka ocieplono wełną mineralną w taki sposób, aby „rysunek” konstrukcji był widoczny od wewnątrz (wypełniono konstrukcję deskami). Był to niezbędny zabieg z uwagi na to, że obiekt funkcjonuje także w okresie zimowym. Kolejną ingerencją i odstępstwem od oryginału było wprowadzenie współczesnych okien zespolonych, uchylno-rozwieralnych w miejsce dawnych, okrągłych, t.zw. „widoków”. Tutaj także był to zabieg niezbędny z uwagi na nowe przeznaczenie obiektu. Obecnie wiatrak pozbawiony jest możliwości nastawiania skrzydłami do kierunku wiatru ze względu na fakt podłączenia doń instalacji wodociągowej, ciepłowniczej i kanalizacyjnej. Zachowano natomiast oryginalny dyszel służący do nastawiania (obrotu) budynku. Możliwość obrotu zachowały zrekonstruowane skrzydła - nie są zatem jedynie atrapą. We wnętrzu wiatraka nie wydzielono odrębnych pokojów, ponieważ zaburzyłoby to właściwy „odbiór” zabytku. Wnętrze stanowi zatem jedną całość, tak jak pierwotnie i jako całość jest wynajmowane turystom. 

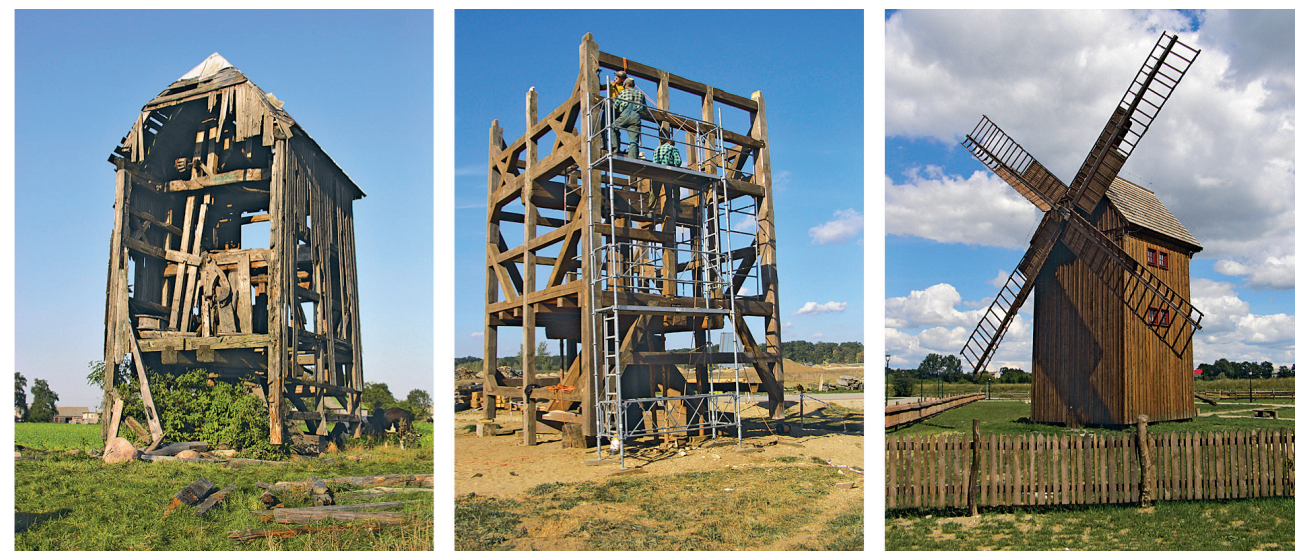

Fot. 2. Wiatrak z Chorzepina przed (25.09.2006 r.) w trakcie $(06.10 .2011$ r.) i po zakończeniu prac konserwatorskich (sierpień 2012 r.), fot. F. Tomaszewski.

Drugi z translokowanych wiatraków, z m. Zbylczyce (Fot. 3), w roku 2000 został zakupiony, udokumentowany i rozebrany przez współautora niniejszego artykułu - F. Tomaszewskiego. Motywem zakupu była decyzja ówczesnych właścicieli o rozbiórce obiektu, co de facto oznaczało jego bezpowrotną zagładę. Wiatrak wtedy nadal był czynny, posiadał jedną parę walców młyńskich pobierających napęd z silnika elektrycznego. Według Katalogu zabytków budownictwa przemysłowego w Polsce obiekt datowany jest na ok. 1870 r. [7]. Obiekt położony był pierwotnie na wzniesieniu pośród pól, następnie został „obudowany” budynkami nowoutworzonego gospodarstwa. Pierwotny kontekst krajobrazowy wiatraka był zatem zaburzony i pomysł jego przeniesienia nie budził większych wątpliwości. W trakcie translokacji udało się zachować ok. 60 \% oryginalnej substancji zabytku. Głównymi przyczynami zniszczeń (korozji biologicznej) była niewątpliwie woda (dostająca się do wnętrza przez zdegradowany, nieszczelny dach) oraz szkodnik techniczny drewna, spuszczel pospolity (Hylotrupes bajulus L.), którego żerowiska zidentyfikowano w wielu miejscach w warstwie bielmowej drewna [8]. Po rozbiórce dokonano kwalifikacji elementów konstrukcyjnych na trzy kategorie:

- typ I - drewno lekko porażone, ale bez oznak zniszczenia lub osłabienia struktury, wymagające czyszczenia, dezynfekcji i dezynsekcji oraz impregnacji;

- typ II - drewno porażone, z lokalnymi uszkodzeniami i osłabieniem warstwy powierzchniowej, wymagające poza zabiegami jak dla drewna typu I także uzupełniania ubytków metodą flekowania;

- typ III - drewno o znacznym lub bardzo dużym stopniu zniszczenia, wymagające wymiany (wiernej rekonstrukcji).

Bezpośrednio po demontażu wiatraka elementy zakwalifikowane do typu I i II zostały poddane dezynsekcji metodą gazowania dwusiarczkiem węgla. Pozostałe czynności konserwatorskie wykonano już na miejscu docelowej lokalizacji obiektu. Ponieważ wiatrak w okresie po II wojnie światowej został przekształcony na młyn elektryczny, niewiele zachowało się z jego pierwotnego, charakterystycznego dla koźlaków wyposażenia. Wymienić tu można jedynie wał skrzydłowy, wialnię zbożową oraz pędnie z wałkami metalowymi. Brakujące urządzenia pozyskano z innych, likwidowanych młynów. Wyposażenie skompletowano $\mathrm{w}$ taki sposób, aby było ono reprezentatywne dla lat 30 . XX w., kiedy wiatraki starano się unowocześniać licząc, że sprostają one konkurencji z coraz wydajniejszymi młynami motorowymi 
[9]. Wyposażenie stanowi zatem autorską kreację projektanta - F. Tomaszewskiego. Program technologiczny obejmuje trzy fazy produkcji mąki: czyszczenie ziarna, przemiał właściwy oraz sortowanie produktu na trzy frakcje - mąkę, kaszkę oraz śrutę. Obecnie wiatrak posiada możliwość nastawiania go do kierunku wiatru. Utrzymanie urządzeń technologicznych w ruchu okazało się jednak problematyczne. Wśród najważniejszych kłopotów wymienić należy:

- czasochłonność czynności opierzania skrzydeł (wypełniania konstrukcji skrzydeł drewnianymi płachtami - w zależności od prędkości wiatru);

- problemy z pędniami pasowymi - złe ustawienie wałów pędni powodujące zsuwanie się pasów z kół pasowych;

- rozciąganie się pasów napędowych, generujące konieczność ciągłego ich napinania (nie pomogły nawet mechaniczne napinacze pasów);

- pojawiające się luzy oraz niedostatecznie sztywne umocowanie panewek wałów pędni;

- problemy z wycentrowaniem wału skrzydłowego i koła palecznego (efekt „bicia” koła palecznego i niewłaściwe jego zazębienie z kołami współpracującymi);

- problemy z utrzymaniem odpowiedniej wysokości górnego kamienia młyńskiego (opadanie kamienia i blokowanie ruchu skrzydeł i pozostałych mechanizmów);

- niedostateczna skuteczność układu hamulcowego przy większych porywach wiatru, co generuje nadmierne drgania całego budynku.

Pojawiające się liczne usterki dają wyobrażenie, jakim kunsztem musieli wykazywać się dawni młynarze, chcąc skutecznie i bez większych perturbacji świadczyć usługę mielenia zboża. W dzisiejszych czasach nawet najlepszy cieśla - konserwator nie sprosta wyzwaniu, jakim jest przystosowanie zabytkowego wiatraka do pracy. Wynika to przede wszystkim z braku doświadczenia i zerwania ciągłości pokoleniowej zawodu młynarza - wiatracznika. Pewnym antidotum może tu być zaangażowanie w prace restauratorskie technologów młynarstwa, niekoniecznie mających doświadczenie z samymi wiatrakami (tacy już w większości nie żyją), ale przynajmniej z młynami o napędzie pędniowym. Budowa „Zagrody Młynarskiej" stała się w pewnym sensie polem doświadczalnym w zakresie utrzymania wiatraka w ruchu. Wiedza i doświadczenie pozyskane w trakcie prób uruchamiania obiektu warta jest popularyzacji w celu uniknięcia podobnych błędów czy to przez placówki muzealne, czy prywatnych inwestorów.
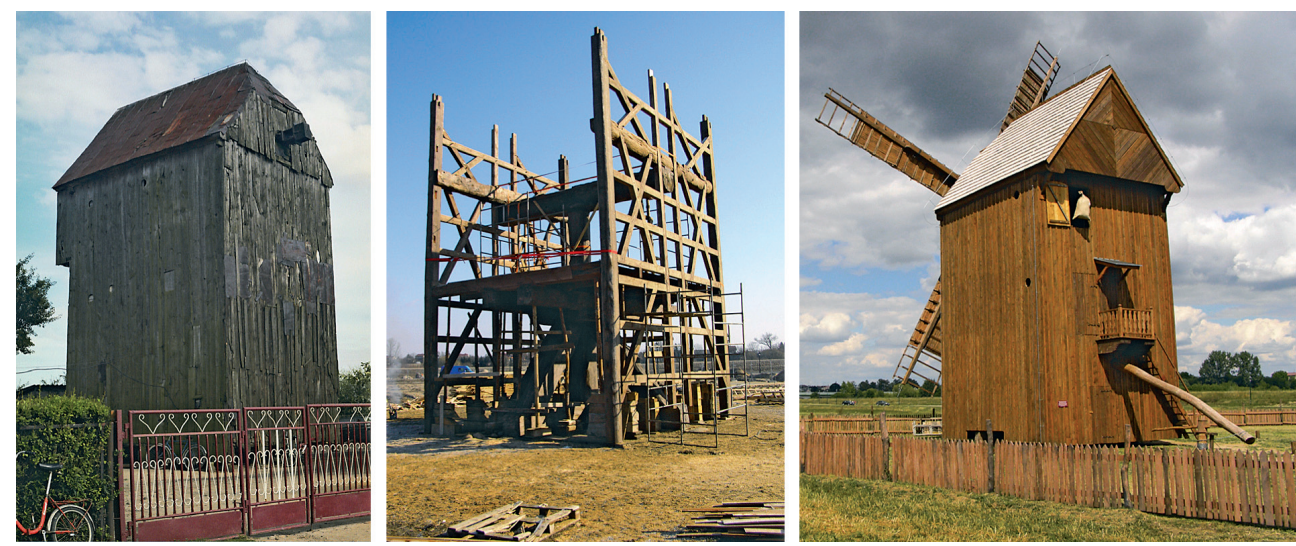

Fot. 3. Wiatrak ze Zbylczyc przed (lipiec 1998 r.), w trakcie (07.03.2012 r.) i po zakończeniu prac konserwatorskich (sierpień 2012 r.), fot. F. Tomaszewski. 


\section{Pozostałe projekty}

Z inicjatywy Muzeum Archeologicznego i Etnograficznego w Łodzi podjęto na przełomie 2011 i 2012 roku translokację zabytkowego wiatraka z m. Zawada w gminie Łęczyca do nowopowstałego skansenu „Łęczycka zagroda chłopska” w Kwiatkówku (również w gminie Łęczyca). Przykład ten jest z punktu widzenia problematyki konserwatorskiej podobny do przykładu translokacji wiatraka ze Zbylczyc (niestety z uwagi na bardzo zły stan techniczny znacznie większy procent elementów budynku podlegał w tym przypadku rekonstrukcji). Kwestia relokacji wyposażenia i znacznego ograniczenia programu technologicznego młyna stanowi temat na odrębny artykuł.

Poza wyżej wymienionymi translokacjami należy także wspomnieć o dwóch remontach przeprowadzonych przy wiatrakach in situ. Są to prywatne młyny w Solcy Wielkiej (gmina Ozorków, powiat zgierski) oraz Rdutowie Nowym (gmina Chodów, powiat kolski), które udało się wyremontować dzięki wsparciu finansowemu i merytorycznemu: Łódzkiego Wojewódzkiego Konserwatora Zabytków, Gminy Ozorków, Urzędu Marszałkowskiego Województwa Łódzkiego (wiatrak w Solcy Wielkiej) oraz Urzędu Marszałkowskiego Województwa Wielkopolskiego (wiatrak w Rdutowie Nowym). Fakt, że w ostatnich latach udało się podjąć prace restauratorskie przy pięciu „łęczyckich” wiatrakach, należy uznać za sukces.

\section{Podsumowanie}

Artykuł niniejszy nie wyczerpuje tematyki związanej z konserwacją i możliwościami zachowania pozostałych wiatraków na terenie dawnego województwa łęczyckiego. Ich dalszy los stoi obecnie pod znakiem zapytania. Niech za podsumowanie posłużą słowa Wiktora Zina, wybitnego konserwatora zabytków, architekta i rysownika: „Kiedyś, w jednym z muzeów Florencji stałem zapatrzony w bezcenne skrzypce Stradivariusa. I wiecie co mnie najbardziej w nich urzekło? Nie ton - bo milczały. Nie forma - obok stały sławne rzeźby. Zafascynowało mnie ich „wypracowanie”. Pod strunami bielił się pył kalafonii. Zaś te części instrumentu, których dotykały palce wirtuoza przybrały barwę i gładkość kości słoniowej. Wierzcie mi lub nie, ale w starym omączonym i wysłużonym wiatraku zachowuję się równie pokornie jak przed gablotą ze skrzypcami Stradivariusa."1

\section{Literatura}

[1] Święch J. Tajemniczy świat wiatraków. Polskie Towarzystwo Ludoznawcze, Łódź 2005, s. 163.

[2] Rutkowska E. Województwo sieradzkie i województwo tęczyckie w drugiej połowie XVI wieku. Cz. 1, Mapy, plany. Atlas historyczny Polski - Polska Akademia Nauk. Instytut Historii. Mapy szczegółowe XVI wieku; 5, cz. 1, Wydawnictwo Instytutu Historii PAN, Warszawa 1998.

[3] Baranowski B. Polskie Młynarstwo. Wrocław, Warszawa, Kraków, Gdańsk: Zakład Narodowy imienia Ossolińskich, 1977, s. 22.

[4] Katalog zabytków budownictwa przemysłowego w Polsce. red. J. Pazdur, t. IV - woj. łódzkie, z. 6 - powiaty Łęczyca i Poddębice, Zakład Narodowy im. Ossolińskich - Wydawnictwo Polskiej Akademii Nauk, Wrocław - Warszawa - Kraków - Gdańsk 1972, s. 32.

[5] Gilly D. Spezialkarte von Südpreussen. org. 1793, skala 1: 50000, redukcja Berlin 1802-1803.

\footnotetext{
Zin W., Stownik krajobrazu polskiego. Wiatraki. [w:] Panorama (tygodnik śląski) - felieton udostępniony na wystawie stałej Muzeum Młynarstwa w Jaraczu.
} 
[6] Bazelmans J., van't Hof J., Nienhuis G., Troost G., Pfeiffer W. A future for mills. Principles for dealing with heritage mills. Cultural Heritage Agency, June 2012, s. 43-46.

[7] Katalog zabytków budownictwa przemystowego..., s. 30.

[8] Kozarski P. Konserwacja domu. Fundacja Ochrony Zabytków i Agencja Omnipress, Warszawa 1992. skala 1: 115000.

[9] Święch J. Wiatraki. Młynarstwo wietrzne na Kujawach. Włocławskie Towarzystwo Naukowe, Włocławek 2001, s. 105-118 (Kierunki modernizacji młynów wietrznych).

\title{
Windmills in Lęczyca district - conservation initiatives from 2006-2017
}

\author{
Filip Tomaszewski, Bartosz M. Walczak \\ Institute of Architecture and Urban Planning, Faculty of Civil Engineering, \\ Architecture and Environmental Engineering, Lodz University of Technology, \\ e-mail: bogdan.tomaszewski@wp.pl,bartosz.walczak@p.lodz.pl
}

\begin{abstract}
Old mills are an essential part of cultural landscape of the area near Łęczyca. The article below presents the initiatives to save and preserve these amazing monuments of wooden architecture. The bad condition of many of them determined (and still determines) wide and differential range of the renovation measures which have been undertaken. They included building a commercial object „Zagroda Młynarska” in Uniejów, formation of the open air museum ,Łęczycka Zagroda Chłopska” in Kwiatówek conducted by Archeological and Etnographic Museum in Łódź and conservation repairs of mills in Solca Wielka and Rdutów Nowy. The relocation of historic windmills creates opportunities to restore them to technical efficiency (it is connected with replacing a significant percentage of their original substance). The article discusses the authenticity which has been achieved in the process of preserving the objects, the range of interference in their original structure, the role of mills in shaping the cultural landscape, but also issues connected with mills' technical equipment and troubles in keeping them still working in good technical condition.
\end{abstract}

Keywords: mill, windmill, renovation, preservation. 